\title{
Clinical Updates on Substance-P Antagonist in Pain Management
}

\author{
Haroon Khan* \\ Department of Pharmacy, Abdul Wali Khan University Mardan 23200, Pakistan
}

"Corresponding author: Haroon Khan Ph.D., M. Phil., B. Pharm, Associate Professor and Chairman Department of Pharmacy, Abdul Wali Khan University Mardan 23200, Pakistan, Tel: +92-3329123171; Email: hkdr2006@gmail.com

Received date: October14, 2014 Accepted date: October 16, 2014, Published date: October 23, 2014

Copyright: (c) 2015 Khan $\mathrm{H}$. This is an open-access article distributed under the terms of the Creative Commons Attribution License, which permits unrestricted use, distribution, and reproduction in any medium, provided the original author and source are credited.

\section{Editorial}

Novel drug designing and development is the need and the decisive target of pharmaceutical industry, as the active life of a drug is not very extensive. Substance $\mathrm{P}(\mathrm{SP})$ is considered as the prototypic neuropeptide of the more than 50 known neuroactive molecules, and is also the member of a new neurotransmitter system that belongs to the family of three related peptides known as neurokinins and a member of the seven-transmembrane G-protein coupled family of receptors and is primarily associated with sensory neurons in the periphery and specific areas of the CNS $[1,2]$. The other two members are simply called neurokinin A and neurokinin B. Modulation of SP activity offered a radical new approach to the management of depression, anxiety, stress and is involved in several physiologic activities, including the vomiting reflex, defensive behavior, change in cardio-vascular tone, stimulation of salivary secretion, smooth muscle contraction and vasodilatation [3,4].

Substance P (SP) and its antagonist represent a radical new approach to the management of a number of diseases. SP is considered to have an impact on the smooth muscles. The SP receptor is highly expressed in areas of the brain that are implicated in these behaviors, but also in other areas such as the nucleus accumbens which mediate the motivational properties of both natural rewards and drugs [5].

The treatments accessible at present for chronic pain conditions are few and their use is limited by the severe side effects of these medications. For years, researchers have been trying to elucidate the molecular mechanisms that underlie central sensitization to develop novel approaches for treating chronic pain conditions. A variety of studies led to the hypothesis that SP and its NK1 receptor are involved in nociception $[3,6]$. However, highly specific antagonists of NK1 are failed to show significant analgesic potential in clinical trials [7], because it is not the NK1 receptor itself, but rather the spinal cord neurons that express NK1 which are pivotal for central sensitization and chronic pain [8]. Actually, they block behavioural responses to noxious and other stressful sensory stimuli at a level detectable in animal tests but fail to provide the level of sensory blockade required to produce clinical analgesia in humans [9]. According to researchers, NK1 receptor is crucial for central sensitization and chronic pain. Study of Mantyh and colleagues, which are based largely on the observations that SP is released upon peripheral noxious stimulation and activates spinal cord nociceptive-specific neurons [10], and that when SP binds to NK1, both SP and NK1 are internalized [11].

For molecular and cellular characterization, synaptic mechanisms underlying the sensitization of spinal cord NK1 expressing neurons are also studied. In that study, whole-cell patch clamp recordings were performed from dorsal horn NK1 expressing neurons in an acute spinal cord slice preparation [12]. Most spino-parabrachial neurones showed the gap-firing pattern while the bursting firing pattern was characteristic of spino-PAG (periaqueductal grey) neurons [13]. Herbert and Holzer has thourghly described hyperalgesic conditions in which NK1 receptor antagonists may be of therapeutic value and discusses possible reasons for the discrepancies between preclinical and clinical trials with NK1 receptor antagonists [14].

New drug designing and development is the current need because treatments currently available for chronic conditions are few and their use is limited by the severe side effects of these medications. The identification and development of novel effective treatments for chronic disorders with minimal side effects is still a challenge. In this regard, enormous progress has been done in synthetic chemistry and biotechnology but still safety profile of these drugs is a big question mark. Modulating SP receptor activity as a therapeutic strategy is the most attractive area of research to design and develop new molecules of meaningful clinical values for tomorrow.

\section{References}

1. Chen W, McRoberts JA, Marvizón JC (2014) Î1/4-Opioid receptor inhibition of substance $\mathrm{P}$ release from primary afferents disappears in neuropathic pain but not inflammatory pain. Neuroscience 267: 67-82.

2. Bassi GS, de Carvalho MC, Brandão ML (2014) Effects of substance P and Sar-Met-SP, a NK1 agonist, in distinct amygdaloid nuclei on anxietylike behavior in rats. Neurosci Lett 569: 121-125.

3. Goldsmith LE, Kwatra MM (2013) Tachykinin/Substance P/ Neurokinin-1 Receptors. In: Lane WJLD, ed. Encyclopedia of Biological Chemistry. Waltham: Academic Press 360-365.

4. Chen YW, Tzeng JI, Lin MF3, Hung CH4, Wang JJ5 (2014) Forced treadmill running suppresses postincisional pain and inhibits upregulation of substance $\mathrm{P}$ and cytokines in rat dorsal root ganglion. J Pain 15: 827-834.

5. Horak J, Dincer C, Bakirci H, Urban G (2014) Sensitive, rapid and quantitative detection of substance $\mathrm{P}$ in serum samples using an integrated microfluidic immunochip. Biosensors and Bioelectronics 58:186-192.

6. Dehlin HM, Manteufel EJ, Monroe AL, Reimer Jr MH, Levick SP (2013) Substance $\mathrm{P}$ acting via the neurokinin-1 receptor regulates adverse myocardial remodeling in a rat model of hypertension. Inter J Cardiol 168:4643-4651.

7. Hamity MV, White SR, Hammond DL (2010) Effects of neurokinin-1 receptor agonism and antagonism in the rostral ventromedial medulla of rats with acute or persistent inflammatory nociception. Neuroscience 165: 902-913.

8. Suzuki R, Rygh LJ, Dickenson AH (2004) Bad news from the brain: descending 5-HT pathways that control spinal pain processing. Trends Pharmacol Sci 25: 613-617.

9. Laird J (2001) Gut feelings about tachykinin NK1 receptor antagonists. Trends Pharmacol Sci 22: 169.

10. Molina-Ortega F, Lomas-Vega R, Hita-Contreras F, Plaza Manzano G, Achalandabaso A, et al. (2014) Immediate effects of spinal manipulation on nitric oxide, substance $P$ and pain perception. Man Ther 19: 411-417. 
Citation: $\quad$ Khan H (2015) Clinical Updates on Substance-P Antagonist in Pain Management. Biol Med (Aligarh) 7: E113. doi:10.4172/0974-8369.1000e113

Page 2 of 2

11. Muñoz M, Coveñas R (2013) Involvement of substance P and the NK-1 receptor in cancer progression. Peptides; 48:1-9.

12. Ikeda H, Heinke B, Ruscheweyh R, Sandkühler J (2003) Synaptic plasticity in spinal lamina I projection neurons that mediate hyperalgesia. Science 299:1237-1240.
13. Ruscheweyh R, Ikeda H, Heinke B, Sandkühler J (2004) Distinctive membrane and discharge properties of rat spinal lamina I projection neurones in vitro. J Physiol 555: 527-543.

14. Herbert MK, Holzer P (2002) [Why are substance P(NK1)-receptor antagonists ineffective in pain treatment?]. Anaesthesist 51: 308-319. 